\title{
Small-scale production in the Congo basin of low-acid carotene-rich red palm oil
}

\author{
Thomas Silou ${ }^{1,2, *}$, Raucy Moussounda-Moukouari ${ }^{2}$, Raphaël Bikanga ${ }^{3}$, Hugues Pamba-Boundena ${ }^{3}$, \\ Tanguy Moussoungou ${ }^{1}$, David Mampouya ${ }^{2}$ and Jean Claude Chalchat ${ }^{4}$ \\ ${ }^{1}$ Pôle d'Excellence Régional 'Alimentation et Nutrition' Faculté des Sciences et Techniques, BP 69 Brazzaville, Congo \\ 2 Ecole Supérieure de Technologie des Cataractes, BP 389 Brazzaville, Congo \\ ${ }^{3}$ Université des Sciences et Techniques de Masuku, BP 901 Libreville, Gabon \\ 4 AVAHEA, La Haye 7, 63500 Saint Babel, France
}

Received 10 October 2016 - Accepted 22 March 2017

\begin{abstract}
The red palm oil consumed in the Congo basin come essentially from small-scale production from the dura or tenera varieties (the latter being a hybrid of dura and pisifera). These three varieties are endemic to the Congo basin. The tenera variety is characterized a thick pulp (about $50 \%$ of the nut) from which $70-90 \%$ of oil (based on fresh pulp) can be extracted. The dura variety has less pulp ( $30 \%$ of the nut by weight), and gives an oil yield of the same order of magnitude. The oil is extracted from the crushed pulp after a series of mixing steps in hot water at about $60^{\circ} \mathrm{C}$. When obtained from freshly harvested nuts (at most 3 days storage), this oil is rich in carotenoids $(800-2600 \mathrm{ppm})$ and polyphenols $(5-13 \mathrm{mg} / \mathrm{g})$, and presents low acid values $\left(I_{\mathrm{A}}<5\right)$ and peroxide values $\left(I_{\mathrm{P}}<10\right)$. Here we describe this traditional production process, widespread in the Congo basin, and suggest innovations that substantially increase the quantity of oil extracted and significantly improve the quality of the end product.
\end{abstract}

Keywords: palm oil / extraction / analysis / Congo basin

Résumé - Production à l'échelle artisanale, de l'huile de palme rouge, riche en carotènes et à faible indice d'acide, dans le bassin du Congo. L'huile de palme rouge consommée dans le bassin du Congo provient essentiellement de la production paysanne à partir de la variété dura ou de la variété tenera (hybride améliorée de dura et pisifera). Ces 3 variétés sont endémiques du bassin du Congo. La variété tenera est caractérisée une pulpe épaisse (environ $50 \%$ de la noix) de laquelle on peut extraire 70-90\% huile (base pulpe fraiche). La variété dura a une pulpe plus fine (30\% de la masse de la noix), conduisant à un rendement en huile de même ordre de grandeur. L'huile est extraite par épuisement de la pulpe à l'issue d'une série de malaxages successifs à l'eau chaude à environ $60^{\circ} \mathrm{C}$. Lorsqu'elle est obtenue à partir de noix fraichement récoltées ( 3 jours de stockage au maximum), cette huile est riche en caroténoïdes $(800$ $2600 \mathrm{ppm})$, en polyphénols $(5-13 \mathrm{mg} / \mathrm{g})$ et présente des indices d'acide $\left(I_{\mathrm{A}}<5\right)$ et de peroxydes $\left(I_{\mathrm{P}}<10\right)$ peu élevés. Le présent article décrit ce procédé de production traditionnel, largement répandu dans le bassin du Congo, et suggère des innovations qui augmentent substantiellement la quantité d'huile extraite et améliorent significativement la qualité du produit final.

Mots clés : huile palme / extraction / analyse / bassin du Congo

\section{Introduction}

The palm oil tree is endemic to the Congo basin in the Gulf of Guinea. Africa was the principal producer of palm oil in the 1960s, but since 2000 it has been largely overtaken by Asia, in particular by countries such as Indonesia (18.3 million tons)

\footnotetext{
* Correspondence: thsilou@yahoo.fr
}

and Malaysia (17.4 million tons), which accounted for two thirds of the world's palm oil production (41 MT) in 20072008. China, India, Pakistan, Bangladesh and Egypt are the main palm oil purchasers (Dronne and Forslund, 2009). The consumption of palm oil rose from $11 \mathrm{~kg}$ to $24.5 \mathrm{~kg}$ per person per year between 1976 and 2006 (Corley, cited by Rival, 2013).

The palm oil tree is exceptionally productive, with an average yield of $3.5 \mathrm{t}$ of oil per hectare. This production 
reaches $7 \mathrm{t} / \mathrm{ha}$ in certain plantations in Asia and $10 \mathrm{t} / \mathrm{ha}$ in experimental stations. Covering $7 \%$ of the crop areas occupied by oil seeds, the palm oil tree produces $30 \%$ of all vegetable oils; palm oil presents the lowest manufacturing costs for vegetable oils, $20 \%$ lower than for oils from soya. Up to $80 \%$ of palm oil is used in foodstuffs (salad oil, frying oil, margarines, fat for baking, pastry-making and other food preparations), about $19 \%$ in oil chemistry (cosmetics, soap, lubricants and greases, candles, etc.) and 1\% as biomass fuel (biodiesel) (Rival, 2013).

Rival (2013) reports that out of the 21 million hectares of primary forest that disappeared in Indonesia between 1990 and 2005 , only 3 million were used to create palm plantations, contrary to general belief. Environmentally friendly palm oil cropping is possible on a reasonable scale.

In Cameroon, palm oil meets $80 \%$ of edible oil needs, with a deficit of $20,000 \mathrm{t}$; in Congo-Brazzaville, more than $80 \%$ of the local palm oil consumed comes from domestic production (Silou, 2012). Likewise in Gabon. This local production mobilizes a significant portion of the actors in the agrifood sector, particularly women. However, the processes used are arduous and the quality of the oil obtained remains substandard.

The local populations of the Congo basin have developed a technique of oil extraction, consisting in the manual mixing of crushed palm nuts with hot water. Oil is collected by gravity after cooling. This process uses a mixer instead of a press. A pilot unit, in the course of optimization, including an ecological palm oil tree plantation (1 ha) and using a $300 \mathrm{~L}$ mixer has been set up in Congo Brazzaville. This paper, which presents the first results of this work, is meant to help small producers in the search for an alternative process, based on local knowledge, for a better production of red palm oil.

\section{Materials and methods}

\subsection{Plant material}

\subsubsection{Experimental palm oil plantation}

For teaching purposes an experimental palm oil plantation was implemented at Loukoko, by the Higher School of Technology "Les Cataractes" (Rural Campus of Loukoko (RCL)) in 1997 with the improved pre-germinated seeds of the tenera variety purchased by the Research Centre and originating from palm oil trees at Pobè in Benin.

This plantation was set up, with a spacing of $10 \mathrm{~m} \times 10 \mathrm{~m}$, in a valley on clay-sand soil on the Plateau des Cataractes (Congo-Brazzaville) exposed to the lower Congo climate, and covering about 1 ha (95 palm trees).

\subsubsection{Raw materials of the oil extraction: Palm nuts}

Three varieties of palm nuts are often found in the Congo basin (Fig. 1): the dura variety, with a thick hull, thin pulp and poor yield, the pisfera variety with a thin hull, thick pulp, generally sterile, and the hybrid variety tenera, with a thin hull, thick pulp and high oil yield, a crossbreed of dura (male) and pisifera (female).

To characterize nuts, the length (main axis) and the width (small axis) of the fruits were measured using a calliper, and the masses of nut, pulp and seed were obtained by weighing with a balance.
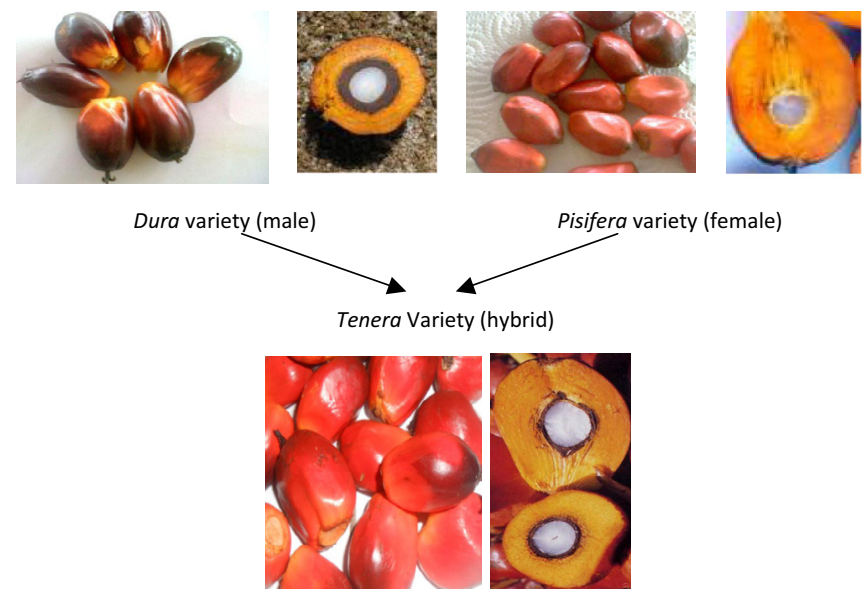

Fig. 1. Palm oil nuts (varieties: dura, pisifera and tenera).

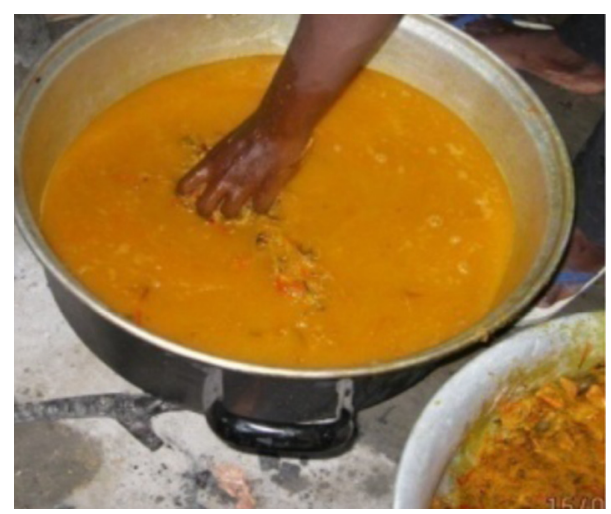

Fig. 2. Mwambe: emulsion of water in oil obtained from crushed nuts mixed manually with hot water (Franceville, Gabon).

\subsection{Traditional process of palm oil extraction}

\subsubsection{Domestic process}

In the Congo basin, housewives transform palm nut into mwambe (emulsion of water in oil) for the preparation of local dishes.

The nuts cooked with water are crushed in a mortar (or pot); the crushed nuts are mixed manually with hot water to give an emulsion of water in oil (Fig. 2), called mwambe or mosaka in Congo Brazzaville. This intermediate product of the process is used to prepare vegetable sauces (Bandzouzi, 2010); the emulsion is heated on a low fire, and the oil separates on cooling; the supernatant oil is collected with a suitable instrument such as a ladle.

\subsubsection{Small-scale process}

The small palm oil producers have adapted the domestic process at craft industry scale (100-200 kg of palm nuts), working in $200 \mathrm{~L}$ reclaimed barrels.

The harvested bunches are stored for 3-4 days to let the nuts soften, which facilitates the separation of the nuts and the extraction of the oil.

The nuts are steamed for $2-3 \mathrm{~h}$ with $50 \mathrm{~L}$ of water to sterilize them (sterilizer step). This steaming also allows easy separation of the pulp and seed. 


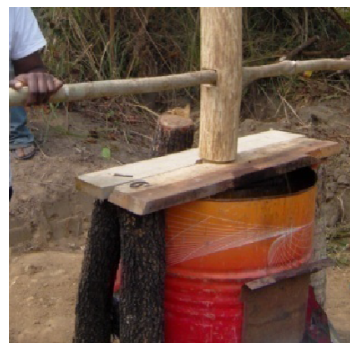

(a) local mixer

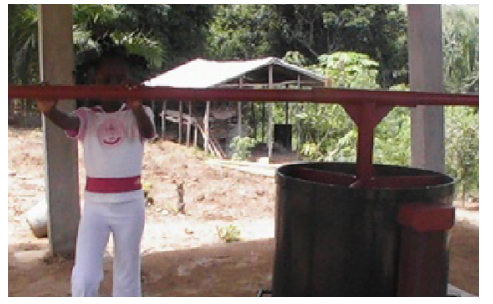

(b) Improved mixer

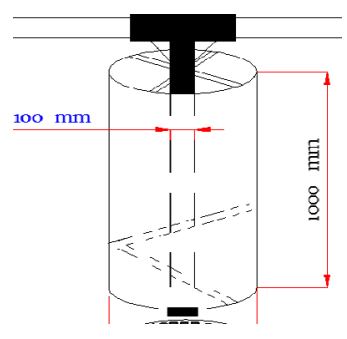

Mixer design

Fig. 3. Artisanal mixers: (a) mixer used by local producers and (b) improved mixer, Rural Campus of Loukoko (RCL).

The oil is extracted from the crushed pulp after a series of mixing steps in hot water $\left(100 \mathrm{~L}\right.$ in all at about $\left.60^{\circ} \mathrm{C}\right)$.

The mixture obtained is gently heated in a clarifier until all yellow foam has disappeared. The mixture is then left to settle and the supernatant dark red oil is skimmed off the aqueous phase.

Sterilization is carried out in a $200 \mathrm{~L}$ barrel $(200 \mathrm{~kg}$ of nuts). The mixer (Fig. 3a) is made of a half-barrel equipped with a hardwood axle on which iron mixing bars are set at right angles. The clarification (defoaming) and the decantation take place in half-barrels.

\subsubsection{Improved small-scale process}

The Higher School of Technology "Les Cataractes" improved the small-scale process by introducing (i) equipment to make the process of extraction of palm oil less arduous, and (ii) procedures and good practices to guarantee the quantity and quality of the final product.

The sterilizer, the mixer (Fig. 3b) and the decanter of capacity $300 \mathrm{~L}$ each, are made of black plate (mild steel); the sterilizer and the decanter are designed to be heated with wood or gas.

The extraction process chain, in a motorized version, will be made of food quality stainless steel at end of the optimization process.

\subsubsection{Modelling of the improved small-scale process: Principal and interaction effects of the factors}

The variables indexed here, which influence the extraction yield, are: quantity of nuts, volume and temperature of the mixing water, time of clarification (decantation) and extraction process.

The dependence of the response of palm oil extraction $Y$ to three unspecified variables $X_{1}, X_{2}$ and $X_{3}$ is expressed mathematically by:

$$
Y=F\left(X_{1}, X_{2}, X_{3}\right),
$$

with $Y$ the response; $F$ the function of the response and $X_{1}, X_{2}$ and $X_{3}$ variables or factors.

The experimentation thus consists in highlighting the effects of these factors on the response.

The factorial design on two levels as developed by Davies (1954) seems sufficiently well-suited to solving this kind of problem, and has the advantage of calling on only very elementary mathematical knowledge (Ortigosa, 1993).
Table 1. Experimental design of the artisanal extraction of red palm oil (tenera variety).

\begin{tabular}{lclll}
\hline Run & Mass $(\mathrm{kg})$ & $T\left({ }^{\circ} \mathrm{C}\right)$ & Method & Response \\
\hline 1 & 50 & 70 & $\mathrm{~A}$ & $\mathrm{Y}_{1}$ \\
2 & 100 & 70 & $\mathrm{~A}$ & $\mathrm{Y}_{2}$ \\
3 & 50 & 90 & $\mathrm{~A}$ & $\mathrm{Y}_{3}$ \\
4 & 100 & 90 & $\mathrm{~A}$ & $\mathrm{Y}_{4}$ \\
5 & 50 & 70 & $\mathrm{~B}$ & $\mathrm{Y}_{5}$ \\
6 & 100 & 70 & $\mathrm{~B}$ & $\mathrm{Y}_{6}$ \\
7 & 50 & 90 & $\mathrm{~B}$ & $\mathrm{Y}_{7}$ \\
8 & 100 & 90 & $\mathrm{~B}$ & $\mathrm{Y}_{8}$ \\
Level -1 & 50 & 70 & $\mathrm{~A}$ & \\
Level +1 & 100 & 90 & $\mathrm{~B}$ & \\
\hline
\end{tabular}

For this design, the mathematical function connecting the response to the factors is a first degree polynomial for each factor, with interaction effects of factors:

$$
\begin{aligned}
y=b_{0} & +b_{1} x_{1}+b_{2} x_{2}+b_{3} x_{3}+b_{12} x_{1} x_{2}+b_{23} x_{2} x_{3}+b_{13} x_{1} x_{3} \\
& +b_{123} x_{1} x_{2} x_{3} .
\end{aligned}
$$

The factors being centred and reduced, the coefficients have simple meanings:

$b_{0}$ average of the response, $b_{i}$ principal effects of the factors, $b_{i j}$ effects of the interactions of order 2 , and $b_{i j k}$ effects of the interactions of order 3.

The experimental design and the matrix of experiments are shown in Tables 1 and 2, according to whether the real or reduced/centred variables are considered.

\subsection{Products obtained}

In two independent consumer surveys conducted in 2009 at Brazzaville (Congo) by Degbia (Degbia, 2010) and in 2013 by Pamba (Pamba-Boundena, 2012) at Franceville, Lambaréné, Oyem (Gabon), samples of oil resulting from the domestic and small-scale processes were collected for a summary evaluation (as an indication) of the quality of the oils consumed in the Congo basin, particularly in the localities concerned.

Samples from the pilot unit (RCL) during the crop seasons 2014-2015 and 2015-2016 underwent physical and chemical analysis (acid values (AV), peroxide values (PV), carotenoid and polyphenol contents, FAs). 
Table 2. Matrix of experiments of the artisanal extraction of red palm oil (tenera variety) (reduced/centered variables).

\begin{tabular}{lccc}
\hline Run & $x_{1}$ & $x_{2}$ & $x_{3}$ \\
\hline 1 & -1 & -1 & -1 \\
2 & +1 & -1 & -1 \\
3 & -1 & +1 & -1 \\
4 & +1 & +1 & -1 \\
5 & -1 & -1 & +1 \\
6 & +1 & -1 & +1 \\
7 & -1 & +1 & +1 \\
8 & +1 & +1 & +1 \\
\hline
\end{tabular}

\subsection{Determination of the chemical characteristics (AV, PV)}

The acid values $(\mathrm{ml} \mathrm{KOH} / \mathrm{g})$ and the peroxide values (mEq. $\mathrm{O}_{2} / \mathrm{kg}$ ) were measured using IUPAC methods, (1979).

\subsection{CG and HPLC analysis}

\subsubsection{Determination of the fatty acid (FA) composition}

The AV $(\mathrm{ml} \mathrm{KOH} / \mathrm{g})$ and the PV $\left(\mathrm{mEq} . \mathrm{O}_{2} / \mathrm{kg}\right)$ were measured using IUPAC methods, (1979). The composition of the oils was determined by gas chromatography using a gas chromatograph (type HP 5890) equipped with a non-polar column (HP 5M, $30 \mathrm{~m}$ long, $0.25 \mathrm{~mm}$ inside diameter and $0.2 \mu \mathrm{m}$ thick) and with a flame ionization detector (FID) in the following experimental conditions:

- Carrier gas helium with constant flow of $1 \mathrm{ml} / \mathrm{mm}$;

- Oven temperature ramp $50-280^{\circ} \mathrm{C}$, at $5^{\circ} \mathrm{C} / \mathrm{min}$;

- Injector temperature $250^{\circ} \mathrm{C}$;

- Detector temperature $280^{\circ} \mathrm{C}$;

- Quantity injected $1 \mu 1$.

The FAs were identified by their respective retention times, and quantified by their peak areas, in the presence of an internal standard at a known concentration (C17:0).

\subsubsection{Determination of triacylglycerol (TAG) composition}

The TAG profile was obtained by high performance liquid chromatography (Héron et al., 2006). The chromatographic system consisted of a model LC-6A pump (Shimadzu, Kyoto, Japan), a model 7125 injector valve with a $10 \mu \mathrm{l}$ loop (Rheodyne, Cotati, CA, USA) and a model Sedex 75 light-scattering detector (Sedere, Alfortville, France). The nebulizing gas was air at 3.5 bars, the evaporation temperature was $37^{\circ} \mathrm{C}$ and the gain (PM) 11 . The column temperature was controlled using an Igloo-CIL column oven (Cluzeau, Sainte-Foy-la-Grande, France) set at $30^{\circ} \mathrm{C}$. An evaporative light-scattering detector (Sedere Sedex 75) was used. AGs were separated at $20^{\circ} \mathrm{C}$ using a Kromacil C18 $(5 \mu \mathrm{m})$, $250 \mathrm{~mm} \times 4.6 \mathrm{~mm}$ column (Part Number KR5C18-25QS $\mathrm{mfg} \# 806610)$ and were eluted from the column with an acetonitrile/dichloromethane mixture (70/30-40/60) (v/v/v). Chromatograms were recorded using Azur (v 3.0), data acquisition software (Datalys, Saint-Martin-d'Heres, France).

\subsection{Evaluation of carotenoid content by UV visible spectrometry}

Carotenes were assayed on a spectrophotometer with a $1 \%$ oil solution in chloroform using the external calibration curves for beta-carotene (standard) plotted by Davis et al. (2007/ 2008) at 460,490 and $520 \mathrm{~nm}$. The linear regression equations at these various wavelengths are:

- to $460 \mathrm{~nm}$ : \% carotenoid $=4.57 \mathrm{Abs}\left(R^{2}=0.989\right)$;

- to $490 \mathrm{~nm}$ : \% carotenoid $=5.60 \mathrm{Abs}\left(R^{2}=0.989\right)$;

- to $520 \mathrm{~nm}$ : \% carotenoid $=25.5 \mathrm{Abs}\left(R^{2}=0.989\right)$.

\subsection{Assay of total phenolics by the Folin-Ciocalteu method}

Total phenolics were assayed by the Folin-Ciocalteu method (Singleton et al., 1999). The external calibration graph uses gallic acid between 0 and $500 \mathrm{mg} / \mathrm{L}$ in a methanol-water mixture as solvent $(0,50,100,250,500 \mathrm{mg} / \mathrm{L})$.

\subsection{Statistical processing}

The descriptive statistics and graphs were run on Microsoft Excel 8.0, the multivariate statistics (Principal component analysis (PCA)) on XLSTAT (www.xlstat.com) and the modelling of the extraction on NEMRODW (lprai@nemrodw. com).

\section{Results and discussion}

\subsection{Characterization of palm nuts and oil}

3.1.1 Fruits of the tenera, dura and pisifera varieties $(\mathrm{RCL})$

Of the four African varieties of palm nuts identified by Adriens in 1951 (macrocarpa, dura, tenera and pisifera), three occur to ranging extents in the Congo basin, and two are of particular economic interest: dura and tenera.

The pisifera variety, considered as sterile, is very seldom found in the wild; about 10 fruits were studied, as shown in Table 3.

It is the smallest of the three varieties, with an average length of $31 \pm 4 \mathrm{~mm}$, width $19 \pm 2 \mathrm{~mm}$, and mass $7.1 \pm 1.1 \mathrm{~g}$ compared with tenera (length $34 \pm 3 \mathrm{~mm}$, width $20 \pm 2 \mathrm{~mm}$, mass: $8.3 \pm 1.1 \mathrm{~g}$ ) and $d u r a$ (length $32 \pm 5 \mathrm{~mm}$, width $24 \pm 3 \mathrm{~mm}$, mass $12.1 \pm 2.7 \mathrm{~g}$ ). With a sphericity index of 0.6 , the fruits of pisifera resemble the fruits of tenera more than they do those of dura (Tab. 3).

The improved tenera variety, generally used for industrial plantations, is now spreading in rural area, particularly in co-operative structures and family businesses.

The fruits of a given bunch of tenera are very similar, as reflected in their low coefficients of variation in length, width, and mass of nuts (Tab. 3). PCA, built on five variables describing nuts, does not permit any classification; fruits are fairly evenly sized in any given bunch (Fig. 4a). The index of sphericity close to 0.5 indicates quasi-spherical globular fruits (Tab. 3).

The tenera variety is the one of most interest for the production of palm oil (oil of pulp). 
Table 3. Statistics, morphological characteristics and biomasses of the nuts from a same bunch of palm oil trees (varieties tenera, dura et pisifera $(R C L))$.

\begin{tabular}{|c|c|c|c|c|c|c|c|}
\hline Varieties & Statistics & Length (mm) & Width (mm) & Mass of nut $(\mathrm{g})$ & Mass of kernel (g) & Mass of pulp (g) & Sphericity $(\mathrm{w} / \mathrm{L})^{*}$ \\
\hline \multirow{2}{*}{ Tenera } & Mean & 34 & 20 & 8.3 & 3.9 & 4.7 & 0.6 \\
\hline & $n$ & 100 & 100 & 100 & 100 & 100 & 100 \\
\hline \multirow[t]{2}{*}{ Dura } & Mean & 31 & 24 & 12.1 & 8.7 & 3.6 & 0.8 \\
\hline & VC (\%) & 16 & 12 & 22 & 44 & 22 & - \\
\hline \multirow[t]{2}{*}{ Pesifera } & Mean & 31 & 19 & 7.1 & 2.7 & 4.3 & 0.6 \\
\hline & VC (\%) & 4 & 2 & 1.1 & 0.7 & 0.9 & - \\
\hline
\end{tabular}

* $L$ : length (main axis); $w$ : width (small axis), $n$ : number of samples; VC: variation coefficient of (\%).

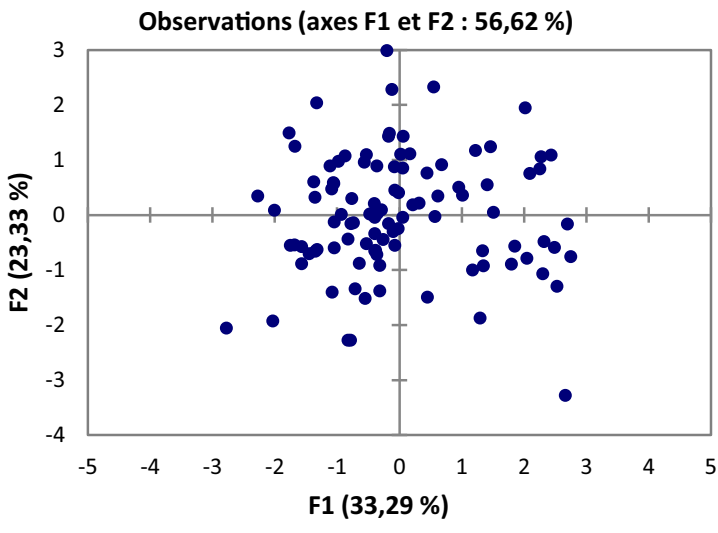

(a)

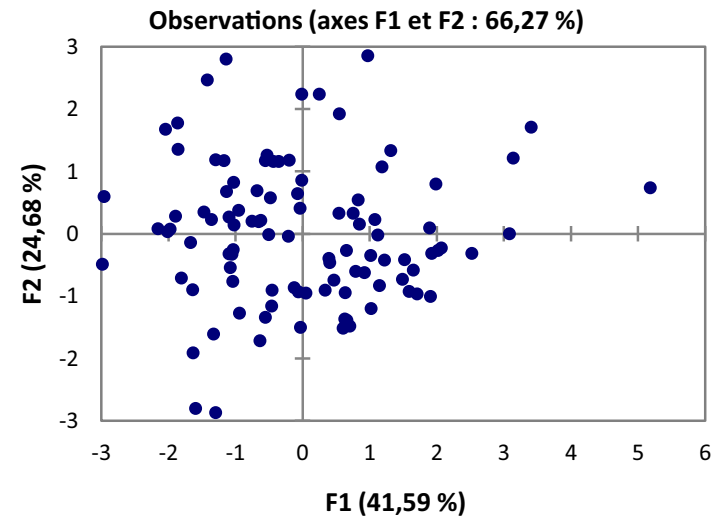

(b)

Fig. 4. Principal component analysis (PCA), built with 5 variables: repartition of individuals on the first principal plan F1F2: (a) tenera variety and (b) dura variety.

Table 4. Pulp and kernel oil content of some samples of dura palm nuts from 9 localities in the Congo basin (triplicate extractions by locality).

\begin{tabular}{lll}
\hline $\begin{array}{l}\text { Number of } \\
\text { localities: } 9\end{array}$ & $\begin{array}{l}\text { Oil content } \\
\text { (pulp) }\end{array}$ & $\begin{array}{l}\text { Oil content } \\
\text { (kernel) }\end{array}$ \\
\hline Mean (VC \%) & $82.4(8)^{*}$ & $48.9(10)^{*}$ \\
\hline
\end{tabular}

* Wet matter basis.

The dura variety is endemic, and used by the local populations in the domestic production of palm oil. The seed of dura, which represents on average $72 \%$ of the fruit mass (Tab. 3), is of commercial value; its kernel also yields significant quantities of oil (Tab. 4).

The oil contents of dura pulp and kernel, from the various localities and according to the AFNOR method (1981) (Tab. 4), highlight very high and very narrowly variable contents (coefficient of variation $(\mathrm{CV})=8 \%$ ) for pulp (mean: $82.4 \%$ ) and high and slightly more variable contents $(\mathrm{CV}=10 \%)$ for kernel (mean: $48.9 \%$ ). The dura variety is thus of interest for its pulp (palm oil) and its kernel (kernel oil).
Table 5. Acid values (AV) and peroxide values (PV) of red palm oils consumed in the Congo and in Gabon.

\begin{tabular}{llrl}
\hline & Sample origin & \multicolumn{1}{c}{ AV } & PV \\
\hline \multirow{3}{*}{ Gabon } & Survey $\left(n=10^{*}\right)$ & $7.7(1.4)$ & $3.1(1.7)$ \\
& P. Mvouma** $(n=5)$ & $8.7(1.8)$ & $3.2(1.7)$ \\
Congo & Survey $(n=12)$ & $24.7(0.8)$ & $8.0(8.0)$ \\
& RCL ${ }^{* * *}(n=9)$ & $6.2(1.8)$ & $3.7(1.8)$
\end{tabular}

AV: acid value; PV: peroxide value.

${ }^{*} n$ : studied sample number.

** Palm Plantation of Mvouma (Franceville, Gabon).

*** Rural Campus of Loukoko (Congo).

\subsubsection{Palm oils}

The 42 samples collected in Congo (Brazzaville (BZV)), Loukoko (LOUK)) and in Gabon (Franceville (FCV), Lambaréné (LAMB), Oyem) during surveys were analysed for an indicative evaluation of their qualities (Tab. 5).

The oils studied seem to vary broadly in status, with a high variability of the two indices considered, namely acid value and peroxide value. 
Table 6. FA composition of local red palm oils sold in markets and colleted from 14 households Brazzaville, Congo).

\begin{tabular}{|c|c|c|c|}
\hline Fatty acids & Formula & Content $(\%)$ & $\begin{array}{l}\text { Mean (SD) } \\
n=14\end{array}$ \\
\hline Lauric acid & $\mathrm{C} 12: 0$ & $\operatorname{tr}$ & - \\
\hline Pentadécanoic acid & $\mathrm{C} 15: 0$ & $\operatorname{tr}$ & - \\
\hline Palmitatic acide & $\mathrm{C} 16: 0$ & $35-42$ & $38.0 \pm 2.9$ \\
\hline Palmitoic acid & $\mathrm{C} 16: 1(n-7)$ & $\operatorname{tr}$ & - \\
\hline Linoleic acid & $\mathrm{C} 18: 2(n-6)$ & $10-15$ & $13.9 \pm 5.5$ \\
\hline Linolenic & $\mathrm{C} 18: 3(n-6)$ & $0.3-0.5$ & $0.4 \pm 0.1$ \\
\hline Arachidic acide & $\mathrm{C} 20: 0$ & $\operatorname{tr}$ & - \\
\hline Cis-11-Eicosénoic acid & $\mathrm{C} 20: 1(n-11)$ & $\operatorname{tr}$ & - \\
\hline Béhénic acid & $\mathrm{C} 22: 0$ & $\operatorname{tr}$ & - \\
\hline
\end{tabular}

$\operatorname{tr}:<0.2 \%$.

Table 7. Composition of fatty acid of palm and kernel oils of tenera and dura varieties of Eleais guinnensis.

\begin{tabular}{lcccccrrr}
\hline & $\mathrm{C} 12: 0$ & $\mathrm{C} 14: 0$ & $\mathrm{C} 16: 0$ & $\mathrm{C} 18: 0$ & $\mathrm{C} 18: 1$ & $\mathrm{C} 18: 2$ & $\mathrm{C} 18: 3$ & $R$ \\
\hline Palm oil "tenera" & 0.00 & 0.84 & 39.86 & 5.42 & 39.98 & 11.38 & 0.35 \\
Palm oil "dura" & - & - & 42.0 & 5.83 & 38.86 & 10.47 & 0.35 \\
Kernel oil "tenera" & 43.53 & 18.13 & 9.75 & 2.3 & 18.25 & 4.01 & 0.00 & 1.0 \\
Kernel oil "dura" & 46.79 & 18.27 & 8.96 & 2.8 & 14.13 & 2.55 & 0.00 \\
\hline
\end{tabular}

$R=\sum \mathrm{sat} / \sum$ insat.

The AV of palm oils from Gabon, collected at markets or in households, or extracted in traditional units, vary over a fairly narrow range (7-10 units), with an average of $7.7 \pm 1.4$. These values are common for crude oils produced locally, but exceed those recommended by the standards.

The situation is completely different in Congo, where the AV of the samples extracted with the equipment and process at the RCL range from 3 to 10, with an average of $6.1 \pm 1.8$. These values are in line with those obtained in Gabon, and those reported in the literature, for crude palm oils (Tan et al., 2009). By contrast, samples collected at the market and in the households and which were stored for ranging times present very high AV between 6 and 35, with an average of $28.7 \pm 1.8$.

These values highlight a deterioration of the oil quality, due to hydrolysis of the TAGs during storage, probably because of the presence of water, enzymes and impurities.

However, these oils, collected from 14 households in Brazzaville and resulting from small-scale production, starting from tenera and/or dura varieties, have an extremely stable FA composition. Table 6 summarizes the composition of these oils, with 16 FAs identified on the samples studied, of which more than two thirds in trace amounts. Four FAs make up almost all the oil (98\%).

They are oils with a low palmitic acid content $(\mathrm{P}$, on average $38.0 \pm 2.9 \%$ ), rich in oleic acid $(\mathrm{O}$, on average
$38.8 \pm 5.0 \%)$ and present a very favourable content of linoleic acid (L, on average $13.9 \pm 5.5 \%)$.

This stable FA profile contrasts with the very high variability and high levels of the AV.

Pulp and kernel of Eleais guineensis give completely different oils. On the other hand, the same parts (pulp or kernel) of dura and tenera varieties have similar FA profiles (Tab. 7).

Table 7 gives the composition of FA of palm and kernel oils are discriminated by the value of:

$$
R=\sum \text { saturated FA/ } \sum \text { unsaturated FA. }
$$

Relative to this indicator, the oils from pulp of tenera and dura are nearly the same ( 0.9 and 1.0$)$; those of seeds contain more saturated FAs than those of pulp (2.7 and 4.4). For seeds, the oil of the dura variety contains more saturated FAs than oil of the tenera variety. Theoretically, the proportion of solids, in oils that are in principle semi-solid, should increase in the order: dura pulp oil $\approx$ tenera pulp oil $<$ tenera seed oil $<$ dura seed oil.

However, the pattern is more complex in practice: the physical state of the oil is also determined by the quantity of saturated FAs present, and its extraction conditions, in particular residual water and suspended solid impurities. Drying and filtration/centrifuging are then required. 


\subsection{Modelling of the small-scale extraction of the palm oil}

3.2.1 Comparison of the small-scale method and the improved small-scale method (RCL)

The process of palm oil extraction used at RCL seeks to improve the traditional process used by the local producers of palm in Plateau des Cataractes (Congo) and largely used throughout the Congo basin.

The performance of the two processes was evaluated using a $2^{3}$ full factorial design (Tabs. 1 and 2). Table 8 shows the responses of the process: palm oil extraction yields $\left(y_{1}\right)$ and palm oil AV $\left(y_{2}\right)$.

The first degree model with interactions led to the following expression:

$$
\begin{gathered}
y_{1}=\mathbf{4 2 . 7 5}-2.750 x_{1}+\mathbf{6 . 2 5 0} x_{2}+2.750 x_{3}-\mathbf{5 . 2 5 0} \boldsymbol{x}_{\mathbf{1}} \boldsymbol{x}_{\mathbf{2}} \\
-1.750 x_{2} x_{3}-0.750 x_{1} x_{3}+0.750 x_{1} x_{2} x_{3},
\end{gathered}
$$

with an average response of $42.8 \%$.

The statistics for the coefficients (giving $R^{2}=0.985$ and $R^{2} \mathrm{~A}=0.897$ ) validate the model selected a posteriori.

Only the mass of nuts has a negative effect on response; the method effect, which has a positive value, compensates exactly for the mass effects. The temperature during the mixing process presents the strongest effect in absolute value and is positive $(+6.250)$.

The effects of second order interaction are all negative with the highest absolute value for the masses/temperature interaction $(-5.250)$.

The third order interaction has a weakly positive effect $(+0.750)$.

Table 8. Palm oil extraction yields $\left(y_{1}\right)$ and palm oil acid values thanks a $2^{3}$ full factorial design.

\begin{tabular}{lll}
\hline Run & Yield $y_{1}(\%)$ & Acid value $y_{2}$ \\
\hline 1 & 28 & 2.8 \\
2 & 36 & 2.2 \\
3 & 56 & 4.5 \\
4 & 40 & 4.5 \\
5 & 54 & 5.0 \\
6 & 42 & 4.5 \\
7 & 58 & 3.9 \\
8 & 42 & 5.0 \\
\hline
\end{tabular}

Examination of the second order interactions from two different full factorial plans (yield $=f$ (method, quantity of nuts, temperature of mixing water) and yield $=f$ (method, quantity of mixing water, temperature of mixing water) highlights the superiority of method B (small-scale improved RCL) over method A (small-scale "local producer"); in all the cases, the extraction leads to a higher yield for B than for A. Increasing (i) nut quantity or mixing water quantity decreases extraction yield, while increasing mixing water temperature increase the yield (Fig. 5).

The average of the responses, the principal and interaction effects of $\mathrm{AV}\left(I_{\mathrm{A}}\right)$ are given in the following expression:

$$
\begin{aligned}
y_{1} & =3.925+0.125 x_{1}+0.550 x_{2}+0.4250 x_{3}+0.150 x_{1} x_{2} \\
& -0.450 x_{2} x_{3}+0.275 x_{1} x_{3}+0.000 x_{1} x_{2} x_{3} .
\end{aligned}
$$

The average of four AV, provided by the model, indicates a good quality of crude oil (freshly extracted). This result validates the process studied a posteriori.

The effects are more marked on $I_{\mathrm{A}}$ (i.e. quality) that on the yield (quantity).

Domestic extraction on very small quantity of fresh palm nuts $(<10 \mathrm{~kg})$ leads to a very good yield and good quality palm oil. The quantity and the quality fall drastically on a small scale $(\geq 100 \mathrm{~kg})$.

The twofold challenge is (i) to make the process less arduous with larger quantities of treated nuts (by greatly reducing effort) and (ii) to solve the problems arising from the conditioning and storage of the oil, which are essentially responsible for the poor quality of crude oil produced in the Congo basin.

\subsubsection{Modelling of the improved small-scale method (RCL)}

The data used and the responses of the $2^{3}$ full factorial design are summarized in Table 9.

In a first degree model, the effects of factors are given by the following polynomial for the yield:

$$
\begin{aligned}
\operatorname{yield}(\%) & =39.37+0.38 x_{1}+0.63 x_{2}+1.13 x_{3}-0.38 x_{1} x_{2} \\
& -0.38 x_{2} x_{3}-0.13 x_{1} x_{3}+0.38 x_{1} x_{2} x_{3} .
\end{aligned}
$$

The average oil extraction yield is about $40 \%$, all principal effects of factors on the response are positive, all second order interaction effects are negative, and the single third order interaction acts positively.

There is a considerable margin for a quantitative improvement of the process to approach $50 \%$ yield, obtained by the small producers on very small quantity of nuts.

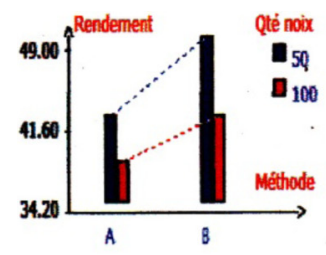

(a)



(b)

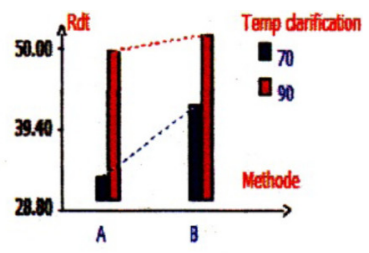

(c)

Fig. 5. Graphic representation of the second order interactions effects (method/quantity of nuts (a), method/quantity of mixing water (b), and method/temperature of mixing water method (c) of palm oil extraction at RCL (Congo). 
Table 9. Experimental design and responses in local extraction of red palm oil of tenera variety at RCL (Congo).

\begin{tabular}{llllll}
\hline Run & Decantation duration $(\mathrm{h})$ & Mixing water temperature $\left({ }^{\circ} \mathrm{C}\right)$ & Mixing water quantity $(\mathrm{L})$ & Yield $(\%) y_{1}$ & Acid value $y_{2}$ \\
\hline 1 & 2 & 70 & 100 & 36 & 3.5 \\
2 & 3 & 70 & 100 & 39 & 39 \\
3 & 2 & 90 & 100 & 39 & 6.8 \\
4 & 3 & 90 & 100 & 5.0 & 7.2 \\
5 & 2 & 70 & 150 & 40 & 3.9 \\
6 & 3 & 70 & 150 & 41 \\
7 & 2 & 90 & 150 & 41 \\
8 & 3 & 90 & 150 & & 8.0 \\
Level -1 & 2 & 70 & 100 & 150 & \\
Level +1 & 3 & 90 & &
\end{tabular}

Table 10. Nuts and red palm oil production of RCL (Congo) (Crop seasons, tenera variety: 2014-2015 and 2015-2016).

\begin{tabular}{|c|c|c|c|c|}
\hline & $\begin{array}{l}\text { Quantity (L) } \\
2014-15\end{array}$ & $\begin{array}{l}\text { Quantity (L) } \\
\text { 2015-16 }\end{array}$ & $\begin{array}{l}\text { Yield (\%) } \\
2014-15\end{array}$ & $\begin{array}{l}\text { Yield }(\%) \\
2015-16\end{array}$ \\
\hline September & 13 & 0 & 31 & 0 \\
\hline November & 137 & 178 & 34.3 & 39.5 \\
\hline December & 228 & 348 & 37.7 & 43.5 \\
\hline March & 65 & 0 & 52.5 & 0.0 \\
\hline April & 24 & 0 & 31.1 & 0.0 \\
\hline May & 50 & 0 & 41.7 & 0.0 \\
\hline Total & 836 & 834 & - & - \\
\hline
\end{tabular}

The model used for acid value gives the following expression:

$$
\begin{aligned}
\text { Acid value } & =6.17-0.45 x_{1}+0.88 x_{2}+0.70 x_{3}+0.10 x_{1} x_{2} \\
& -0.27 x_{2} x_{3}+0.45 x_{1} x_{3}+0.825 x_{1} x_{2} x_{3} .
\end{aligned}
$$

The process gives an oil with an average acid value of 6.17 . The quantity and the temperature of the mixing water have a positive effect on this index, while the duration of the decantation process has a negative effect. The positive effects are overall twice higher, in absolute values, than the negative ones.

There are also good prospects for qualitative improvement of the process with the extraction equipment in the course of optimization.

\subsection{Quantitative and qualitative evaluation of the production of palm oil by the improved small-scale process (RCL)}

\subsubsection{Quantitative evaluation}

The RCL crop season covers the period from September (year $n-1$ ) to May (year $n$ ). Table 10 gives the results of the market years 2014-2015 and 2015-2016. Figure 6 recapitulates the evolution of this production in a graph.

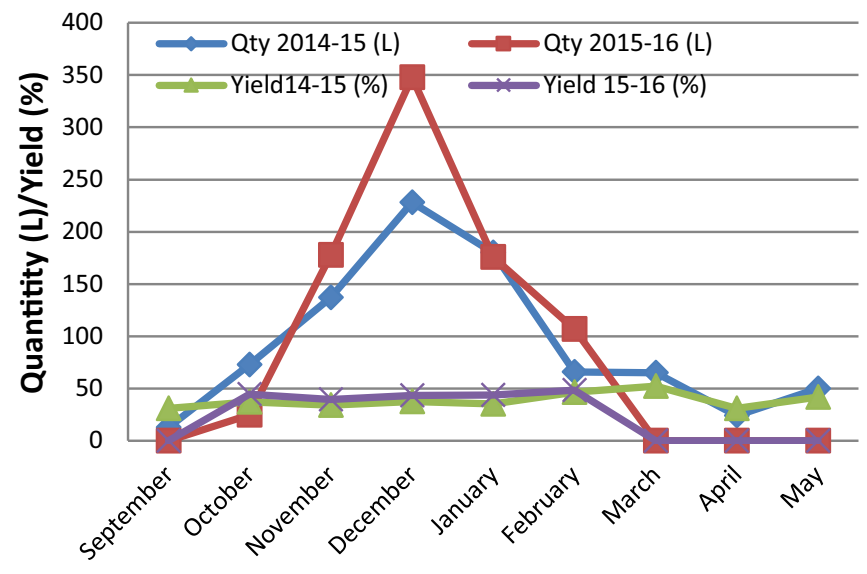

Fig. 6. Nut and red palm oil productions of tenera variety from RCL (Congo) (Crop seasons: 2014-2015 and 2015-2016).

This figure makes it possible to date the beginning and end of the crop season, and also to highlight that about half of the oil produced during a market year was produced within 1 month.

The near-constant oil extraction yield $(\mathrm{CV}=7.2 \%$ for the marketing year 2014-2015 and $\mathrm{CV}=3 \%$ for 2015-2016) shows an excellent control of the process by the workers in 
Table 11. Glyceride fraction of tenera palm oil from RCL (Congo), Côte d'Ivoire and Malaysia.

\begin{tabular}{|c|c|c|c|}
\hline $\begin{array}{l}\text { References } \\
\text { Constituents }\end{array}$ & $\begin{array}{l}\text { Present work } \\
\text { Contents (\%) }\end{array}$ & Côte d'Ivoire (1) & Malaysia (2) \\
\hline \multicolumn{4}{|l|}{ Glycerides class } \\
\hline Monoglycerides & 0.0 & NA & NA \\
\hline Diglycerides & 6.7 & NA & NA \\
\hline Triglycerides & 91.6 & NA & 4.9 \\
\hline $\mathrm{T} 48$ & 3.8 & NA & 7.4 \\
\hline T50 & 47.4 & NA & 42.6 \\
\hline T52 & 41.2 & NA & 40.5 \\
\hline T54 & 7.5 & NA & 8.8 \\
\hline \multicolumn{4}{|l|}{ FA profile } \\
\hline Palmitoléic acid (C16:1n7) & 0.1 & ND & ND \\
\hline Oleic acid (C18:1n9) & 40.1 & 48.6 & 39.2 \\
\hline Linoleic acid (C18:2n6) & 11.3 & 9.2 & 10.1 \\
\hline$\alpha$-Linolenic acid (C18:3n3) & 0.3 & 0.3 & 0.4 \\
\hline
\end{tabular}

(1) Mondé et al., 2008; (2) Tan, 1989, Tan et al., 2009; NA: not available; ND: not detected.

Table 12. Unsaponifiable fraction of tenera palm oil (RCL (Congo) and literature data).

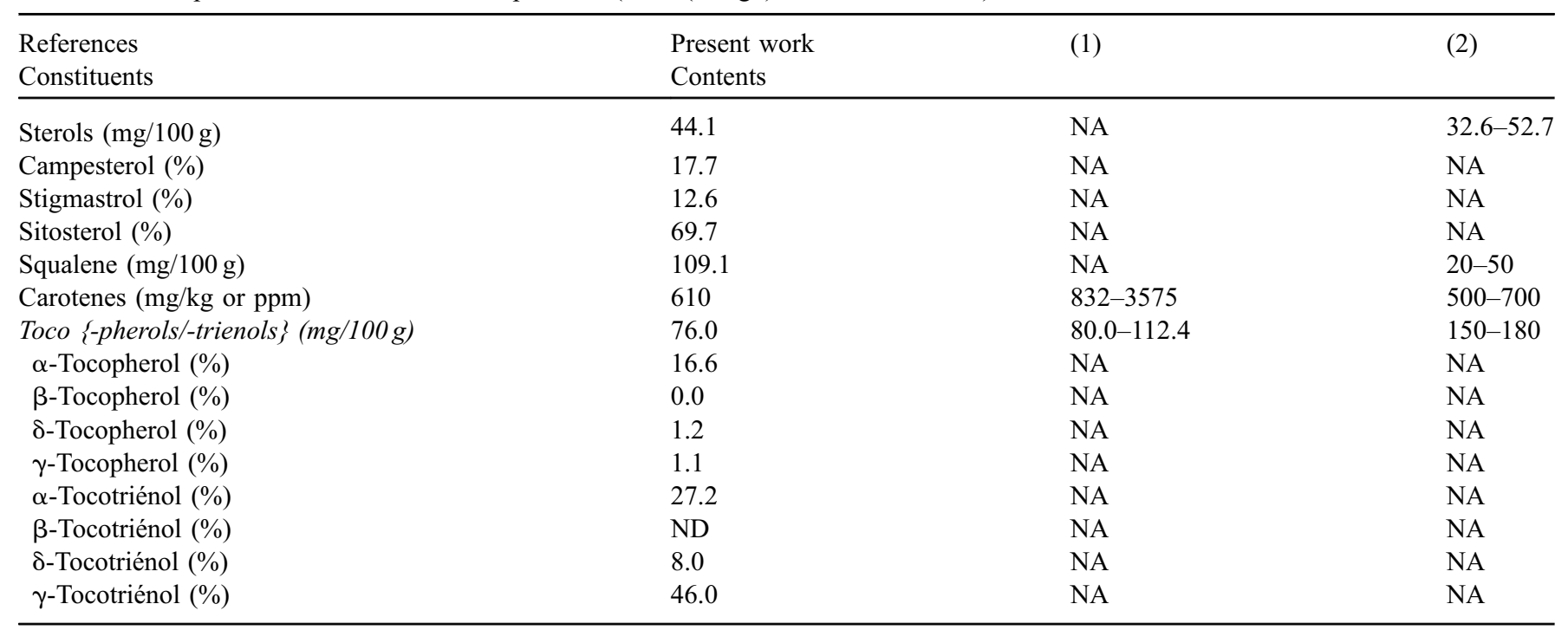

(1) Mondé et al., 2008; (2) Kouski et al., 2015; NA: not available; ND: not detected.

charge of the extraction at the RCL. With an extraction yield of $49 \%$ in 2014-2015 and 56\% in 2015-2016, the RCL extraction process using a mixer is much better than most of the processes used for palm oil extraction.

\subsubsection{Fine chemical characterization of the palm oil from $\mathrm{RCL}$}

A detailed study of the glyceride and unsaponifiable fractions of RCL palm oil gives the results shown in Tables 11 and 12 .
The palm oil studied consists of nearly $91.6 \%$ of triglycerides, $6.7 \%$ of diglycerides and $1.7 \%$ of free fatty acids FFAs). Two classes of the identified TAGs constitute $88.6 \%$ of the total (T50 and T52), the remainder counts two others (T48: $3.8 \%$ and T54: 7.5\%). It is a palmito-oleo-linoleic type oil with $\% \mathrm{P} \geq \% \mathrm{O}>\% \mathrm{~L}$ (POL), and a cumulated content of more than $90 \%$. Stearic, myristic, linoleic, arachidic and palmitoleic acids are minor components (Tab. 11).

This profile is consistent with that reported in the literature for Malaysia (Tan et al., 2009 and cited references) and Ivory Coast (Mondé et al., 2008). 
Table 13. Fatty acid chemical composition of palm oils from the Congo RCL crop season: 2014-2015 and Gabon.

\begin{tabular}{|c|c|c|c|c|c|}
\hline & \multicolumn{5}{|c|}{ Fatty acid contents $(\%)$} \\
\hline & C16:0 & $\mathrm{C} 18: 0$ & C18:1 & C18:2 & $\mathrm{C} 18: 3$ \\
\hline \multicolumn{6}{|c|}{ CONGO (Rural Campus of Loukoko, $n=41)$} \\
\hline Standard deviation & 2.15 & 1.47 & 2.24 & 1.87 & 0.16 \\
\hline \multicolumn{6}{|c|}{ GABON (Plantation Mvouma $n=5$ ) } \\
\hline Mean & 36.14 & 5.57 & 39.51 & 9.13 & 0.25 \\
\hline
\end{tabular}

$n=$ number of samples studied.

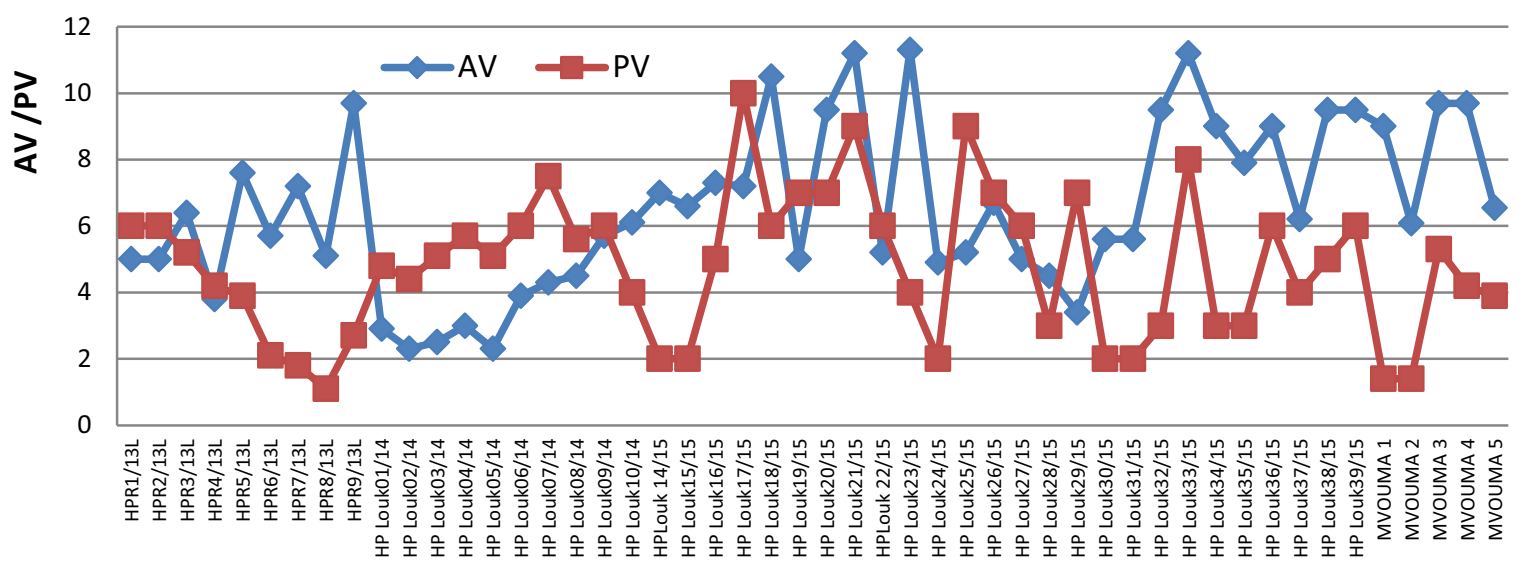

Fig. 7. Variation of acid values $(\mathrm{AV} ; \mathrm{ml} \mathrm{KOH} / \mathrm{g})$ and peroxide values $\left(\mathrm{PV}, \mathrm{mEq} . \mathrm{O}_{2} / \mathrm{kg}\right.$ ) for palm oils samples of tenera variety from Rural Campus of Loukoko (Congo) and oil Palm Plantation Mvouma (Franceville Gabon).

Red palm oil has a high carotenoid content $(610 \mathrm{mg} / \mathrm{kg})$. The beta sitosterol is the most abundant sterol (69.7\%) for a total sterol content of $44.1 \mathrm{mg} / 100 \mathrm{~g}$ and tocopherols together with tocotrienols (tocols) is present at $76.1 \mathrm{mg} / 100 \mathrm{~g}$ with $\gamma$-tocotrienol expressed this value into $\mathrm{mg} / 100 \mathrm{~g}(46.0 \%)$ as a major constituent (Tab. 12).

\subsubsection{Qualitative evaluation of the oils produced at RCL (2014-2016)}

(i) Physical and chemical characteristics

Crop seasons 2014-2015 and 2015-2016 used the improved small-scale process (RCL), and the oil obtained was systematically analysed at the exit of the oil mill $(48 \mathrm{~h}$ at most for 2015-2016, and 1-2 months maximum for 20142015 for the physical and chemical characteristics). Five samples from Franceville produced by local producers (Palm Plantation MVOUMA) were also examined.

The AV measured range from 2 to 12 , with an average roughly between 4 and 10 for the great majority of samples (Fig. 7).

These studies also establish that after a strong increase (more than 100\%) in the first week following the extraction, these values fall back to the starting level. This could explain why the indices measured at $48 \mathrm{~h}$ after the extraction are of the same order of magnitude as those measured several months after extraction.
The values obtained are higher than those of WHO standards; they can be improved by minor innovations in the process (e.g. quality of extraction water, or drying and purification of oil by centrifugation).

The presence of free water and suspended impurities, which support the hydrolysis of the TAGs, explains the increase in $\mathrm{AV}$ in the first 2 weeks after extraction.

In a study from Cameroon, Pondo Pondo (2010) notes, here also, a very marked increase in the IP during the first month following the extraction, and a fall in this value with the decomposition of the peroxide formed, returning to starting values beyond 2 months.

(ii) Composition in FAs and structure of the triacyglycerols (TAGs)

The FA composition of the palm oils extracted from the tenera variety (RCL) closely resemble that of tenera and dura oils produced by the small producers and purchased on the market of Brazzaville (Tabs. 6 and 13, Fig. 8)

Palmitic and oleic acids alternately take first and second place in the samples studied, and stearic and linoleic acids follow in third and fourth positions. These four FAs constitute more than $95 \%$ of total FAs.

Palm oil is representative of oils and fats frequently found in the Congo basin, and are palmito-oleo-linoleic type oils (POL).

With nearly $50 \%$ of saturated FAs, Dubois et al. (2008) classify palm oil in the saturated FA group and under the 


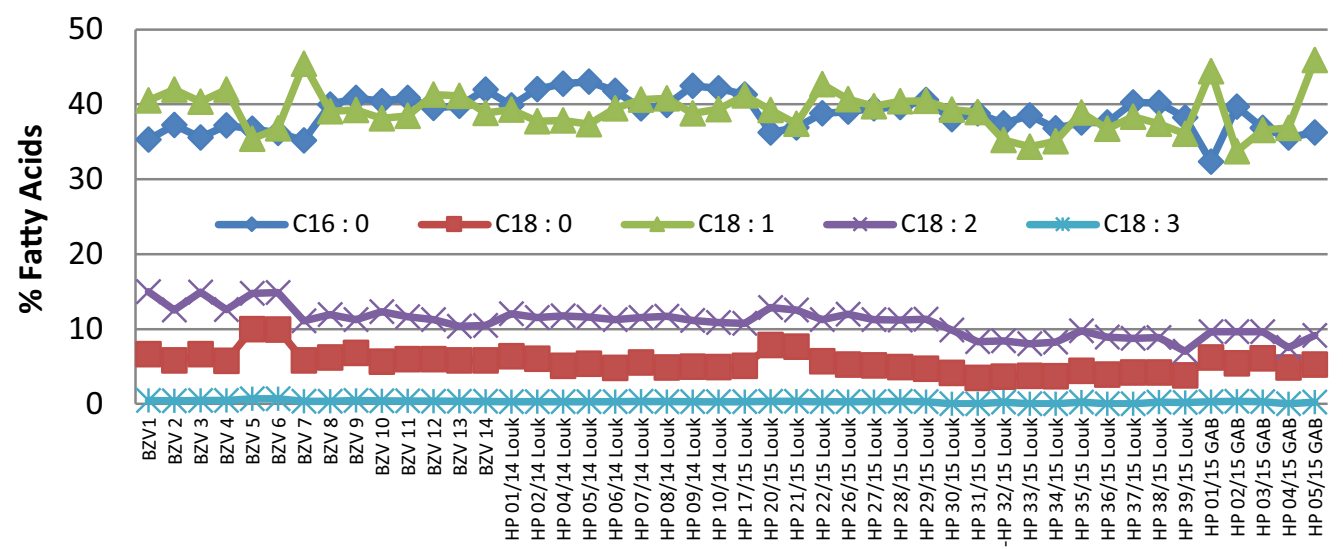

Fig. 8. Variation of fatty acid Composition (\%) of palm oils of tenera variety from the Congo (RCL crop season: 2014-2015) and Gabon (Plantation Mvouma).

palmitic acid sub-group, while Salas et al. (2009) classify them among oils rich in palmitic acid.

Since the other $50 \%$ of palm oil is composed of unsaturated FAs, we previously suggested distinguishing between a mixedfat group, a significant source at the same time of saturated FAs, mono-unsaturated FAs and poly-unsaturated FAs, alongside the groups that are sources of only one FA or one family of FAs: saturated, mono-unsaturated or polyunsaturated (Silou, 2014).

Such a classification allows a better evaluation of the nutritional utility of the palm oil, and similar oils in the Congo basin, e.g. Raphia laurentii, R. sese, Dacryodes edulis, Canarium schweinfurthii and Luffa cylindrica.

This utility should take into consideration the presence of a very high content of oleic and linoleic acids, unsaturated FAs, as a positive nutritional contribution (Dubois et al., 2008).

When using TAGs as classification elements of fats, we distinguish external $(s n 1,3)$ from internal $(s n 2)$ bonding positions of FAs on glycerol: this distinction casts a new light on the status of palmitic acid in the palm oil, and in other palmito-oleo-linoleic type oils.

As reported by Lecerf (2013), palm oil has only $11 \%$ of its palmitic acid in position 2 , and $87 \%$ of the FAs in position 2 are unsaturated $(\mathrm{O}$ and $\mathrm{L})$, so that most of the palmitic acid is in position $1-3$.

Palmitic acid can increase LDL cholesterol ("bad" cholesterol), particularly when it is in the internal position on glycerol.

Stereospecific analyses of the POL type oils establish that palmitic acid is fixed preferentially on the 1-3 positions of glycerol, and oleic and linoleic acids, preferentially in position 2 , with an advantage for linoleic acid, according to Litchfield on the bonding priority of FAs on TAGs (Litchfield, 1972).

Palmitic acid occupies 1-3 positions in oils of raphia (Silou et al., 2012) and safou (Kinkéla and Bézard, 1993; Silou and Kama-Niamayoua, 1999, Kinkéla and Silou, 2004). Oleic and linoleic acids preferentially occupy the internal position, with a slight advantage for linoleic acid, which is di-unsaturated.

The stability of the palm oil FA profile leads to a stable TAG profile, around a standard composition presented in Table 14. Two TAGs, PPO and POO, constitute $72 \%$ of the total TAGs. Five other TAGs are in the list, with a cumulated contribution of $23 \%$ and an individual contribution in the range 4-7\%: POL, PPL, (PPP + SOO), PSO. Only PPP is formed by
Table 14. Typical triacylglycerol composition of RCL palm oil (tenera variety). S, P, O, and L means: stearic, palmitic, oleic and linpleic acids.

\begin{tabular}{llcl}
\hline $\begin{array}{l}\text { References } \\
\text { TR }\end{array}$ & Triacyglycerols & $\begin{array}{l}\text { Present work } \\
\text { Contents }(\%)\end{array}$ & Malaysia* \\
\hline 19.33 & OLL & 0.13 & 0.5 \\
20.1 & PLL & 0.7 & 2.5 \\
21.97 & OOL & 0.44 & 1.7 \\
22.77 & POL & 5.85 & 9.9 \\
23.59 & PPL & 5.24 & 9.5 \\
24.04 & NI & 0.61 & ND \\
24.57 & OOO & 0.78 & 4.3 \\
25.04 & SOL & 0.55 & ND \\
25.46 & POO & 22.79 & 22.8 \\
25.9 & PSL & 0.51 & ND \\
26.36 & PPO & 49.79 & 29.0 \\
27.37 & PPP + SOO & 7.68 & 7.9 \\
28.56 & PSO & 4.01 & 5.1 \\
29.59 & PPS & 0.71 & 1.0 \\
30.67 & SSO & 0.17 & 0.5 \\
31.68 & NI & 0.06 & ND \\
& & 0.00 & 5.3 \\
& Other & 100 & 100 \\
& & & \\
& Total & & \\
\hline
\end{tabular}

*NA: not available; ND: not detected.

three saturated FAs $(\mathrm{P})$, carrying palmitic acid in the internal position of glycerol. The other TAGs containing at least one unsaturated FA have this position preferentially occupied by this acid.

\section{(iii) Carotenoid content}

Carotenoid contents were determined on $1 \%$ oil in chloroform at $460 \mathrm{~nm}$ using an external calibration curve of beta-carotene over an absorbance range from 0 to 3 . The curve due to Davis et al., 2008/2009: \% carotenoid $=4.67 \times$ absorbance $\left(r^{2}=99\right)$ gives a carotenoid content in the range $400-1000 \mu \mathrm{g} / \mathrm{ml}$, consistent with those in the literature, which 




Fig. 9. Variation of caroteinoïd contents in samples of tenera variety from RCL (Congo) and Palm Plantation Mvouma (Gabon).

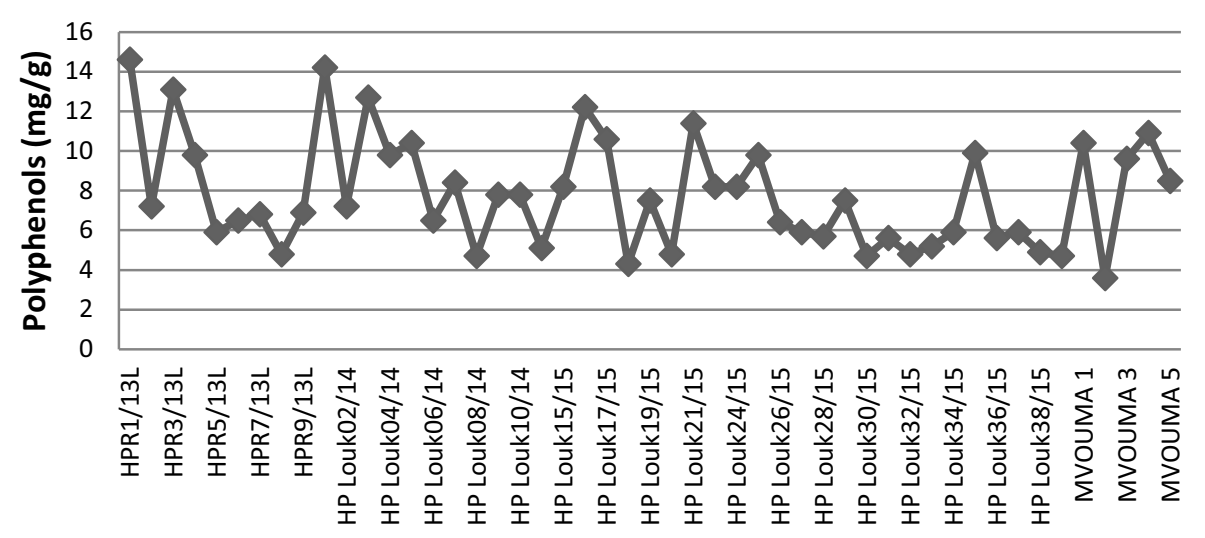

Fig. 10. Variation of polyphenol contents in samples of tenera variety from RCL (Congo) and Palm Plantation Mvouma (Gabon).

generally range between 500 and 700 ppm (Swoboda, 1985; Tan, 1989), and between 800 and $3575 \mathrm{ppm}$ for the most powerfully improved hybrids at certain research centres (Mondé et al., 2008).

Variations in carotenoid contents of the oils studied are shown in Figure 9. The carotenoid content values of the main samples range from 500 to $1000 \mu \mathrm{g} / \mathrm{g}$, attesting the good quality of the oils studied.

\section{(iv) Polyphenol content}

Polyphenol contents were determined according to the method of Folin-Ciocalteu (Singleton et al., 1999) using an external calibration curve plotted with gallic acid for concentrations ranging from 0 to $600 \mathrm{ppm}$ and yielding the equation:

$$
\mathrm{Abs}=0.0051 \mathrm{C}_{2}(\mathrm{ppm})+0.0492\left(r^{2}=0.994\right) .
$$

Results obtained on oils from Congo and Gabon are reported in Figure 10. The samples studied, which are rich in polyphenol compounds, present good anti-oxidant properties (4-14 mg/g).

These values are close to those obtained for oils of colza $(5-7 \mathrm{mg} / \mathrm{g})$, soya $(2-7 \mathrm{mg} / \mathrm{g})$ and sunflower $(4-9 \mathrm{mg} / \mathrm{g})$ by pressing followed by solvent extraction (Régis et al., 2016).

They are higher than that of the olive oils extracted by traditional processes in Tunisia $(0.2 \mathrm{mg} / \mathrm{g}$, Mirouane et al.), and much lower than that obtained on improved palm plantations in an experimental research station $(64-130 \mathrm{mg} / \mathrm{g})$ by Mondé et al. (2008).

\section{Conclusion}

Red palm oil, extracted by the traditional method, is very widely consumed in the countries of the Congo basin particularly in Cameroon, the Congo, DR Congo and Gabon. This traditional production process is arduous, and the product quality is poor compared with standards (low yield of $25 \%$ with the dura variety, high acid and PV, low carotenoid content, etc.). Substantial improvements made to the process during this work on the equipment (powerful mixer, steam sterilizer, modern clarifier and modern decanter) and on the process (modelling) permit gains in both quantity (yield around 50\%) and quality (low acid value of around 4 ; very low peroxide index of around 6; high carotenoids (600-1200 ppm) and polyphenols $(4-15 \mathrm{mg} / \mathrm{g}))$. Other improvements are in progress, including (i) the use of food-quality stainless steel, (ii) motorization of the mixer, and (ii) the introduction of a centrifugal filter for oil drying, should further improve the quantitative and qualitative gains already obtained at mid-course.

Acknowledgements. The authors thank Dr. Z. Mouloungui (Research Director, INRA/INP-ENSIACET Toulouse, France) and his team, for the detailed analysis of palm oil 
from the RCL (Congo Brazzaville), and Dr L.C. ObameEngonga and Dr. S.A. Ondo Azi, from the University of Sciences and Technology of Masuku (USTM), Franceville (Gabon) for their important contribution in the part relating to polyphenols.

\section{References}

Adriens EL. 1951. Les oléagineux du Congo Belge. Ministère des Colonies, 2nd ed. Bruxelles: Royaume de Belgique, pp. 29-43.

Bandzouzi EMF. 2010. Séchage de la pulpe de noix de palme (Elaeis guineensis). Qualité de la "mouambe" reconstituée. Mémoire de DEA. Brazzaville, Congo : Bibliothèque Université Marien Ngouabi.

Davies OL. 1954. Design and analysis of industrial experiments. London: Olivier \& Boyd, 7 p.

Davis AR, Fish WM, Perkings Veazie P. 2008/2009. A rapid spectrophotometric method to determine beta-carotene content in Cucumis melo germplasm. Cucurbit genetic cooperative Report 31/32, pp. 5-7.

Degbia D. 2010. Étude de consommation urbaine sur les oléagineux et corps gras en zone CEMAC. Cas de Brazzaville. Mémoire de DEA. Brazzaville, Congo : Bibliothèque Université Marien Ngouabi.

Dronne Y, Forslund A. 2009. Le rôle croissant des huiles tropicales sur les marchés internationaux: principaux acteurs et produits. OCL 16: 184-192.

Dubois V, Breton S, Linder M, Fanni J, Parmentier M. 2008. Proposition de classement des sources végétales d'acides gras en fonction de leur profil nutritionnel. $O C L$ 15: 56-75.

Héron S, Maloumbi MG, Dreux M, Verette E, Tchapla A. 2006. Method development for a quantitative analysis performed without any standard using an evaporative light-scattering detector. J Chromatogr A 1162: 152-156.

IUPAC. 1979. Méthodes d'analyses des matières grasses et dérivés, 6th ed. Paris, France: Lavoisier Tec et Doc, 190 p

Kinkela T, Bezard J. 1993. Étude de la structure des triacylglycérols de l'huile de la pulpe de safou (Dacryodes edulis). Rev Fr Corps Gras 11/12: 373-382.

Kinkela T, Silou T. 2004. Composition en acides gras et en triacylglycérols de l'huile de la graine de safou. J Soc Ouest-Afr Chem 17: 19-31.

Kouski M, Nahidi M, Cheraghali F. 2015. Physico-chemical properties, fatty acid profile and nutrition in palm oil. J Para Sci 6: 117-134.
Lecerf JM. 2013. L'huile de palme: aspects nutritionnels et métaboliques. Rôle sur les risques cardiovasculaires. OCL 20: 147-159. DOI: 10.1584/ocl.2013.0507.

Litchfield C. 1972. Analysis of trigycerides. New York: Academic Press.

Mondé AA, Michel F, Carbonneau MA, et al. 2008. Teneur en acides gras et antioxydants de l'huile de palme en Côte d'Ivoire. Pharma Méd Tradit Afr 15: 11-17.

Ortigosa C. 1993. Planification expérimentale en chimie. Bull CIFEC 7: 46-57.

Pamba-Boundena HR. 2012. Caractérisation et qualité de l'huile de palme et de la pâte d'odika (Irvingia gabonensis) consommée à Franceville au Gabon, Mémoire de master. Franceville, Gabon: Université des Sciences et techniques de Masuku.

Rival A. 2013. Palmier à huile : défis et questions à la recherche. $O C L$ 20: 133-142. DOI: 10.1684/ocl.2013.0506.

Salas JJ, Bootello MA, Martinez-Force E, Garcès R. 2009. Tropical vegetable fats and butters: properties and new alternatives. $O C L$ 16: $254-258$.

Silou T. 2012. Oils and fats for the future. Case study Safou: Dacryodes edulis from Congo basin countries. NY, USA: Nova Edition Publisher, $120 \mathrm{p}$.

Silou T. 2014. Corps gras non conventionnels du bassin du Congo: caractérisation, biodiversité et qualité. OCL 21: 209. DOI: $10.1051 / 2013044$

Silou T, Kama-Niamayoua R. 1999. Contribution à la caractérisation des safous (Dacyodes edulis) d'Afrique centrale. V. Note sur l'étude régiospécifique des triacylglycérols de l'huile de la pulpe de safou par spectrométrie RMN ${ }^{13} \mathrm{C}$. Résultats préliminaires. OCL 6: 349-353.

Silou T, Goteni S, Makondzo Mondako C, et al. 2012. Oils from raphia species from Congo basin: composition, biodiversity and quality. Recent Progr Med Plant 34: 237-268.

Singleton VL, Orthofer R, Lamuela-Raventos RM. 1999. Analysis of total phenols and other oxidation substrates and antioxidants by means of Folin-Ciocalteu reagent. Methods Enzymol 299: $152-178$

Swoboda PAT. 1985. Chemistry refining. J Am Oil Chem Soc 62: 287-292.

Tan B. 1989. Palm carotenoids, tocopherols and tocotrienols. J Am Oil Chem Soc 66: 770-776.

Tan CH, Ghazali H, Kuntom A, Tan CP, Arifin AA. 2009. Extraction and physicochemical properties of low fee acid crude palm oil. Food Chem 113: 645-650.

Cite this article as: Silou T, Moussounda-Moukouari R, Bikanga R, Pamba-Boundena H, Moussoungou T, Mampouya D, Chalchat JC. 2017. Small-scale production in the Congo basin of low-acid carotene-rich red palm oil. OCL 24(5): D504. 